\title{
A SURVEY METHOD TOWARDS AN EFFECTIVE EMISSION MONITORING WITHIN THE URBAN ENVIRONMENT: A CASE STUDY IN THE PORT OF NAPLES (ITALY)
}

\author{
MARCO CASAZZA ${ }^{1}$, GIORGIO VARCHETTA ${ }^{1}$, NICOLA PIROZZI $^{1}$, ROBERTA TETA ${ }^{2}$, \\ SERGIO ULGIATI ${ }^{1} \&$ MASSIMILIANO LEGA ${ }^{1}$ \\ ${ }^{1}$ University of Naples Parthenope, Italy \\ ${ }^{2}$ University of Naples Federico II, Italy
}

\begin{abstract}
Pollution monitoring in the urban environment is an issue of paramount importance both for public health and for the environment, and in relation to the need of finding adequate solutions towards a more sustainable lifestyle. This is particularly true in the case of areas where specific activities or intense emissions occur. This is the case, for example, of ports. In fact, harbours are important for economic and social development of coastal areas, but they also represent an anthropogenic source of emissions, often located near urban centres and industrial areas. In order to define the characteristics and the boundaries of these critical areas, a method for conducting a survey has been defined and tested. The purpose of this work is to define a methodological approach for particulate matter (PM) monitoring of a given extended source. This article introduces a specific case study in the port of Naples (Southern Italy). A preliminary survey approach for defining the setup and operational conditions for a monitoring network has been defined. In this research a key role is played by the use of innovative devices, having a higher spatial and temporal resolution with respect to standard reference instruments, which already proved to be effective means in supporting the survey actions.
\end{abstract}

Keywords: 3D monitoring, air pollution, environmental monitoring, harbour, PM, port

\section{INTRODUCTION}

Air pollution is a subject of major concern, due to its adverse effects both on the environment and on human health. Many historical documents already report the existence of polluted air in towns prior to the modern industrial era. Concern about the effects of air pollution has existed for centuries. In 14th-century England, regulations were introduced regarding the burning of sea coal, and violators were tortured for producing foul odours. In the United States, the first air pollution regulations also dealt with coal, and in the 19th century, coal and smoke ordinances were passed in Chicago, St. Louis and Cincinnati. In the 20th century, concern about air pollution in the United States can be traced to severe pollution episodes, such as the 1948 episode in Donora, Pennsylvania (near Pittsburgh), which resulted in nearly 7,000 illnesses and 20 deaths. We cannot forget the existence of so-called 'smog crises', which still affect various part of the world. Apart from St. Luis, we must quote the tragedy that befell Greater London: from 5 December through 9 December 1952 a heavy, motionless layer of smoky, dusty fumes from the region's million or more coal stoves and local factories settled in the London basin. This fog became known as the 'Big Smoke', because its toll and the public reactions to it were without precedent [1].

Among the different air pollutants, particulate matter (PM) deserves a great attention because of its impacts. In fact, it increases mortality and morbidity, while it decreases lung function [2]. In most epidemiological studies, health effects are related to the mass concentration of particles with diameter less than $10 \mu \mathrm{m}\left(\mathrm{PM}_{10}\right)$ [3]. PM are usually classified as $\mathrm{PM}_{10}$ (particles with an aerodynamic diameter - $\varnothing$ - less than $\left.10 \mu \mathrm{m}\right), \mathrm{PM}_{2.5}(\varnothing<2.5$ 
$\mu \mathrm{m})$ and $\mathrm{PM}_{1}(\varnothing<1 \mu \mathrm{m})$. The coarse fraction (belonging to the size class: $2.5 \mu \mathrm{m}<\varnothing \leq 10$ $\mu \mathrm{m}$ ) is predominantly originated by natural sources (geological material - such as fugitive and resuspended dust - and biological material - such as pollen and endotoxins), while its composition changes depending on the geology of the site considered. Coarse particles are mainly deposited in the extrathoracic region, while some inhaled fine particles reach the alveolar region of the lung [4]. The PM coarse fraction has been associated with proinflammatory and cytotoxic effects $[5,6]$. On the other side, the PM fine fraction $\left(\mathrm{PM}_{2.5}\right.$ and its sub-fraction, $\mathrm{PM}_{1}$ ) are dominated by combustion-derived particles, consisting mainly of both organic and inorganic elements adsorbed onto the surface of a carbonaceous core and of secondary particles, produced by photochemical reactions in the atmosphere (sulphates and nitrates) [7]. The carbonaceous fraction consists of aggregates of organic and inorganic carbon, on which transition metals $(\mathrm{Pb}, \mathrm{Cd}, \mathrm{V}, \mathrm{Ni}, \mathrm{Cu}, \mathrm{Zn}, \mathrm{Mn}, \mathrm{Fe})$, organic compounds and biological constituents are adsorbed [8]. $\mathrm{PM}_{2.5}$ has been associated mainly to a higher genotoxic potential $[9,10]$. While, in the past, the attention was mainly concentrated on these effects, new evidence is emerging about PM role, as neurotoxic agent, in neurodegenerative processes $[11,12]$.

Cities are currently home to nearly half of the world's population. By 2030 each of the major regions of the developing world will host more urban than rural dwellers; by 2050 fully two-thirds of their inhabitants are likely to live in urban areas [13]. The strong increase of urban population, on one side, and the need of a transition towards a more sustainable lifestyle, on the other side, can be the reasons of a call for action in reducing the existing environmental pressures, among which PM occupies a relevant place. In fact, PM and precursors are released by human activities in every part of the world, but the concern is growing, particularly for areas of rapid economic growth and high population density [14].

Several factors, behind their origin, influence the characteristics of PM. Local climate and topography are known variables influencing air pollution levels [15]. The conditions can be particularly troublesome, if the affected city is located in a valley surrounded by mountains $[16,17]$. The influence of local meteorological factors is related both to the aerosol generation processes and to transport and scavenging phenomena. In fact, meteorology is important for understanding the degradation of $\mathrm{SO}_{2}, \mathrm{NO}_{2}$ and $\mathrm{NH}_{3}$, leading to secondary aerosol formation [18]. In particular, temperature and solar radiation enhance the formation of $\mathrm{O}_{3}, \mathrm{H}_{2} \mathrm{SO}_{4}$ and $\left(\mathrm{NH}_{4}\right)_{2} \mathrm{SO}_{4}$, while relative humidity enhances the transformation of $\mathrm{NO}_{2}$ to form $\mathrm{HNO}_{3}$ and $\mathrm{NH}_{4} \mathrm{NO}_{3}$ [19]. The aerosol transport by wind has been studied and described in different areas [20]. Aerosol in-cloud scavenging [21] and removal processes by precipitations [22, 23] and by fog [24] are also known.

The presence of specific economic activities constitutes another important factor in influencing the characteristics of PM. This is the case, for example, of ports. Harbours are important for economic and social development of coastal areas, but they also represent an anthropogenic source of emissions, often located near urban centres and industrial areas [25, 26]. The main pollutants emitted by ship traffic are nitrogen oxides, sulphur oxides and particulate matter that represent, globally, 5-7 Tg/year, 4.7-6.5 Tg/year and 1.2-1.6 Tg/year, respectively [27]. In general, ship emissions will increase in the next $10-40$ years due to growth in international trade [28]. It is important to remark that nearly $70 \%$ of the ship emissions occur within $400 \mathrm{~km}$ of land [26]. Thus, close-to-land emissions could have significant environmental impact on the coastal areas [29]. In-port ship emissions and the emissions of harbour-related activities represent only a small fraction of the global emissions associated with shipping [30]. However, they can have an important environmental effect on coastal regions in Europe, Asia and the United States, which often have harbours located near urban and industrial centres [31, 32]. 
Specific case studies were also analysed [33-38]. The multiple and complex nature of port emissions constitutes a further thread for the health of exposed citizens in the neighbouring urbanized coastal areas. Thus, pollution monitoring becomes important, as a first step in order to develop appropriate and effective countermeasures to reduce the impacts. Furthermore, it can support the port authority in identifying more appropriate actions in the transition towards a more sustainable management of such an economic activity.

There is no universal way of defining a priori the characteristics of air pollution monitoring in relation to ports, since, as discussed before, the number of variables which determine the level of air toxicants is really high. The first step is, anyway, to define an emission zone of influence. In the case of PM, this area is defined, referred to a given emitter, as the distance from that specific source, which contributes no more than $10 \%$ of the measured PM concentration [39]. Nonetheless, in our specific case, we are dealing with an extended source. Thus, it is also necessary to define the spatial uniformity with respect to our site. This parameter is defined as the extent to which particle concentrations vary over a specified area. Furthermore, it is expressed as a spatial coefficient of variation of measured concentrations from many samplers in an area and as the deviation of measurements taken by a single sampler from the spatial average of all samplers. In particular, an annual coefficient of variation (standard deviation divided by the mean) of less than $10 \%$, and a $20 \%$ maximum deviation of a single sampler from the mean, are desirable indicators of spatial uniformity for determining compliance with standards. The second value can be assessed using a different reference time period (day, month, etc.). Furthermore, the reference periods for the comparisons must be homogeneous.

In order to define both the existence of such a heterogeneity and, consequently, the resolution grid for a future monitoring network, a preliminary survey is indispensable. The purpose of this work is to define a methodological approach for this operation, in the case of PM. A specific case study will be introduced, then, in the case of the port of Naples (S Italy).

\section{MATERIALS AND METHODS}

This research is focused on the methodological approach of a preliminary survey for defining the setup and operational conditions for a monitoring network. Such a set of measuring instruments should also be capable of detecting the internal variability of a complex and distribute ensemble of PM sources, as a sub-system of a given environment, with a different ensemble of emitters. A port, located within an urban area, can be a practical example of what has just been defined in a general way. Three criteria should be considered: the boundaries of the monitored system, the horizontal homogeneity and the vertical homogeneity. The survey is used to give a preliminary definition of these characteristics.

It is obvious that difficulties arise since we are dealing with an open sub-system; there are two main difficulties: defining the boundaries of such an area and defining the existence of separable components, which should reflect somehow the different activities within the environment under study. The answer to the first problem comes from EPA [39], as described in the introduction. The existence of non-homogeneities for PM emissions is a known fact. For example, in a previous study by Pinto et al. [40], the spatial variability of $\mathrm{PM}_{2.5}$ concentration was demonstrated in the urban areas of the United States, which revealed a meaningful difference among eastern and western sites. While the definition of homogeneous sub-areas for PM monitoring is again defined by EPA [39], further indications can be derived from experiences in similar fields, such as meteorology.

In fact, also in this case, each network contains an organized collection of individual sensors, which gather measurements that are representative of the micro-, local- or mesoscale, 
depending on the network objectives. Furthermore, the atmospheric processes (or pollutant dynamics, in our case) that are to be observed, and the size and morphology of the area being covered, will affect the physical arrangement of the network - such as the distance between the sensors, the sensor heights and the precise location of the sensor - and thus the network scale. City-scale networks focus on urban processes by using networks of instruments that allow sufficient coverage. While an urban area could be considered a mesoscale phenomenon, mesoscale networks are not specifically designed to resolve the urban climate. Instead, dense climate networks covering whole cities are required to examine the urban climate in more detail [41]. Moreover, measurements taken by each sensor are considered representative of the local area (and not the microscale).

Routine monitoring activities for atmospheric pollutants usually neglect the three-dimensionality of atmospheric diffusion. Nonetheless, apart from the nature of this phenomenon, there is another reason for including the vertical dimension into these operations. In fact, the vertical city has become both a planning paradigm and a reality since the 20th century [42]. Furthermore, a great part of the exposed population lives indoor for a meaningful fraction of day. Furthermore, three different environments have been classified: home indoor, work indoor and other indoor [43]. Finally, it is a well-known fact that a relation exists between indoor and outdoor PM pollution [44]. This is why a 3-D survey would be strongly recommended.

A final remark about the instrumentation. Monitoring networks with stationary equipment gives indeed a quantitative impression of prevailing average concentrations near the instrumental site. Troublesome situations ('hot-spots'), however, are usually not discovered in the network's data [45]. This is why the use of mobile instrumentation, characterized by a hightime-resolution sampling, is preferable.

\subsection{Case study, measurement techniques and facilities}

The study was conducted in narrow portions of the city of Naples (S Italy), so as to verify whether the variability of PM concentrations is detectable in relatively limited urban volumes. First, the definition of a set of such 2-D spaces is necessary to associate a given volume with a sampling station. In addition, PM values can display a vertical variability. This depends on the height of the buildings, on the layout of the road network, leading to the formation of different urban canyons, as well as on the different natural morphology of the terrain, which can vary within a few kilometres. Moreover, a change in exposure to weather conditions affects the particulate matter and therefore on its variability in terms of concentration.

The port of Naples was chosen for our survey (Fig. 1). Its position is in the central part of the city, close to high-traffic roads. Such a case is representative of an emission area of interest, almost surrounded by an extended source, represented by the urban environment of Naples. This makes, on one side, the definition of port boundaries with respect to PM pollution more difficult. On the other side, the characteristics of the site are representative for testing the methodological approach that we introduced in the previous section. The port area, selected for the survey, is about $0.11 \mathrm{~km}^{2}$. The choice of a narrow part of the port depends on the fact that it is open to the public (this increases the exposed population), while it is also the part closest to the city centre and, so, to the boundaries of the system under analysis. At the port area of Naples, the measurements were taken at nine different points (Fig. 2). These were chosen at the berths where ferries and hydrofoils arrive, depart and station. The nine points $(1,6,7,-2,5,8,-3,4,9)$ represent three different port transepts. 


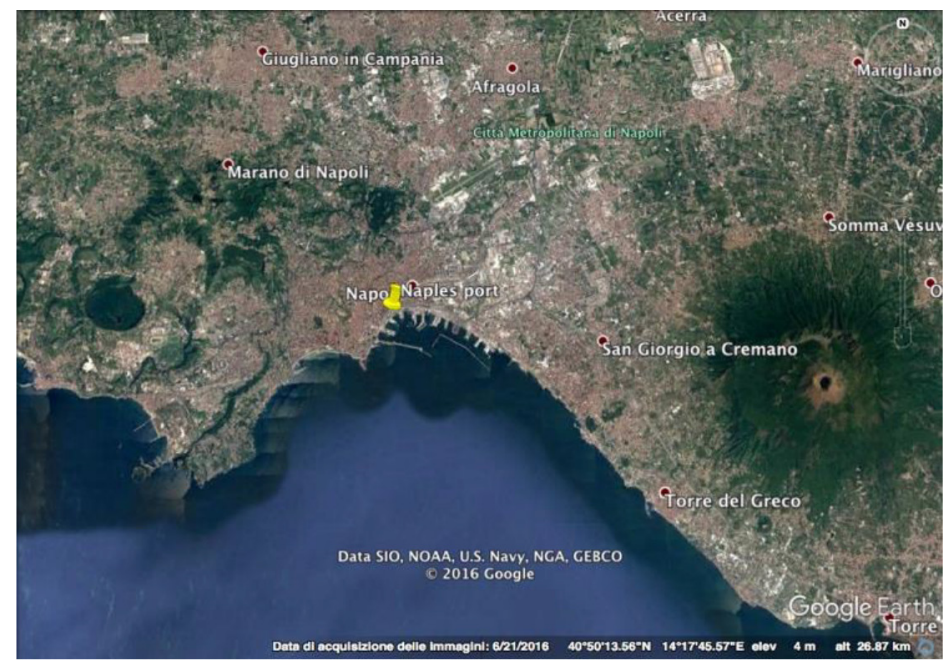

Figure 1: Location of the Port of Naples (S Italy) using Google Earth.

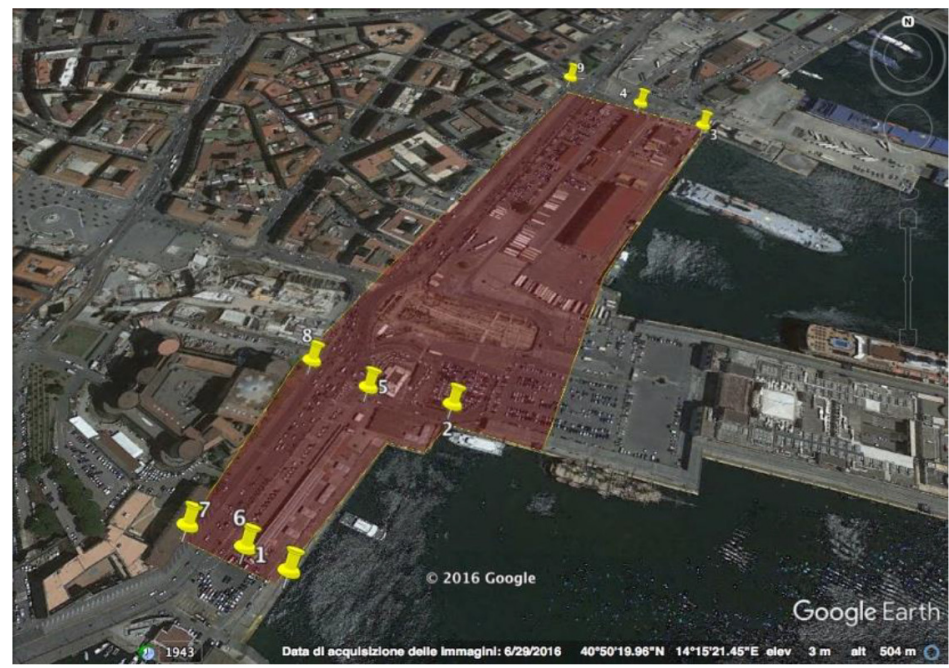

Figure 2: The sampling area (red polygon) and the nine sampling points in the Port of Naples.

The study of the particulate matter concentrations was carried out through a Novaetech PMR Drone - Particle Monitoring Recorder (Fig. 3), produced by Novaetech. This is an innovative prototype for automatic fine PM measurements in micrometre and sub-micrometre range, based on Quartz Crystal Microbalance (QCM) technology. The main components of this instrument are a replaceable inlet (a nozzle, which dynamically selects the PM size), an impact surface (i.e. the quartz crystal), a micro air pump, the operating system and a Wi-Fi transmitter (based on Arduino technology). This tool has been previously tested and used in different field campaigns. In particular, this instrument has proven to be compact, with low power consumption and simple PC interfaces. Being extremely lightweight and compact, this 


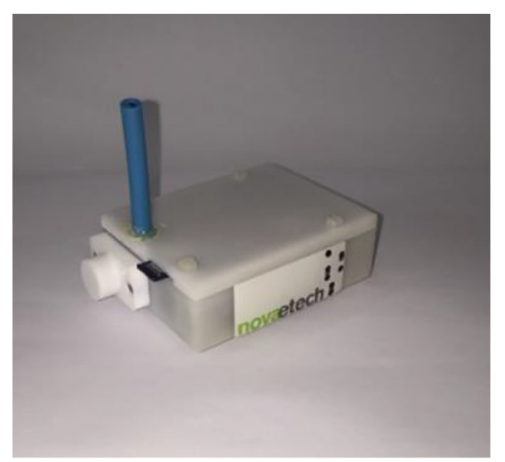

Figure 3: Novaetech PMR Drone (Particle Monitoring Recorder).

tool can be placed on board of any type of vehicle, from where it can sample time sequences, with a variable high-time resolution, usually fixed at 1 minute. The sensor core, made up of piezoelectric element, allows, by means of a set of gravimetric measurements, to determine the particulate mass concentration.

The working principle is inertial impaction coupled with the QCM technology. In particular, QCM technology allows to take advantage of the piezoelectric characteristics of quartz surface. The PM concentration is defined as a function of oscillation frequency variations, generated by the deposition of particles on the impact surface. This principle is based on a study by Sauerbrey [46], who developed an equation that relates the mass and with frequency variations through a coefficient, $C_{\mathrm{f}}$ :

$$
\Delta f=-C_{\mathrm{f}} \cdot \Delta m
$$

In particular, $\Delta f$ is the variation of observed frequency, in $\mathrm{Hz} ; \Delta m$ is the mass change per unit area, in $\mathrm{g} / \mathrm{cm}^{2} . C_{\mathrm{f}}$ is the sensitivity factor of the used crystal, defined as:

$$
C_{\mathrm{f}}=2 \cdot n \cdot \frac{f_{0}^{2}}{\sqrt{\rho_{q} \cdot \mu_{q}}}
$$

where $n$ is the number of harmonic sequence to which the crystal is driven; $f_{0}$ is the crystal resonant frequency, in $\mathrm{Hz} ; \rho_{q}$ is the density of quartz; $\mu_{q}$ is the quartz shear modulus.

The PMR Drone was fixed over a rack of a bicycle, 1 metre above the surface. Each measurement cycle lasted 10 minutes, with a sampling resolution of 1 minute. The weather conditions were assessed, in order to guarantee the homogeneity of the sampling conditions.

The option of defining the vertical profiles along the survey for each chosen sampling point was considered. Since the purpose of this article is methodological, the data will not be reported for the sake of simplicity. As a general comment, the technological operative support derived from the use of flying drones appeared to be really useful in this case. The effectiveness of our advanced environmental monitoring based on the combined use of physical, [47-53] chemical [54, 55] and biological [56] surveys has been already validated in previous studies; in particular, several missions were performed to detect and identify polluted areas due to environmental violations. 


\section{RESULTS AND DISCUSSIONS}

The mean $\mathrm{PM}_{2.5}$ mass concentrations, measured in nine different points of the Port of Naples, are collected in Table 1 . The measured values are assessed against mean daily data of the closest $\mathrm{PM}_{2.5}$ measuring station (the data are publicly available from the Regional Environmental Protection Agency - ARPAC). Only one datum falls within the $20 \%$ deviation, which indicates the presence of a homogeneous area with respect to a reference point. This means that the collected measures represent a different physical reality from the one chosen as reference (the ARPAC measuring station). Thus, the existence of a different homogeneous reference area is confirmed, showing the validity of the survey approach. Furthermore, the available monitoring system appears to be insufficient and non-representative for the territory of Naples for the monitored pollutant.

Non-uniform data appear among the different days. This difference depends on the different weather stability classes, classified according to Pasquill [57], observed along the sampling periods. In particular, the data can be grouped considering day 1 and day 2 together as a first block. Correspondingly, day 3 and day 4 can be associated in a second group. A planimetric variability of $\mathrm{PM}_{2.5}$ is also visible. This depends on the variable intensity, number and distribution of sources within the considered area. This evidence, which is important for a survey, would not appear using traditional techniques and fixed monitoring stations.

Considering the position of the nine points, it is also possible to deduce that PM emissions from ferries give a higher contribution to the measured values. In fact, points from 1 to 6 generally exhibit larger values with respect to the ones measured in the other sampling sites. In contrast, road traffic does not influence the obtained dates in a very significant way. This variability might depend on the orography and, more particularly, on the presence of the Vomero Hill behind the port building, acting as a natural barrier for the wind.

In order to better visualize the planimetric variability, a three-dimensional modelling is superimposed to the aerial view of the port area (Fig. 4). The dimension of each block, which

Table 1: Mean $\mathrm{PM}_{2.5}$ mass value in the nine sampling points at the port of Naples. Day 1: 13 July 2016. Day 2: 14 July 2016. Day 3: 19 July 2016. Day 4: 20 July 2016. The datum marked with $(*)$ is the only one that falls within the $20 \%$ limit with respect to the daily mean value of the closest reference $\mathrm{PM}_{2.5}$ measuring station.

\begin{tabular}{ccccc}
\hline $\begin{array}{c}\text { Measurement } \\
\text { point number }\end{array}$ & $\begin{array}{c}\mathbf{P M}_{2.5}(\mathbf{d a y} \mathbf{1}) \\
{\left[\frac{\boldsymbol{\mu g}}{\boldsymbol{m}^{\mathbf{3}}}\right]}\end{array}$ & $\begin{array}{c}\mathbf{P M}_{2.5}(\text { day }) \\
{\left[\frac{\boldsymbol{\mu g}}{\boldsymbol{m}^{\mathbf{3}}}\right]}\end{array}$ & $\begin{array}{c}\mathbf{P M}_{2.5}(\text { day 3) } \\
{\left[\frac{\boldsymbol{\mu g}}{\boldsymbol{m}^{\mathbf{3}}}\right]}\end{array}$ & $\begin{array}{c}\mathbf{P M}_{2.5}(\text { day 4) } \\
{\left[\frac{\boldsymbol{\mu g}}{\boldsymbol{m}^{\mathbf{3}}}\right]}\end{array}$ \\
\hline 1 & 55 & 55 & 125 & 26 \\
2 & 54 & 76 & $25\left(^{*}\right)$ & 43 \\
3 & 65 & 52 & 3 & 21 \\
4 & 101 & 81 & 2 & 3 \\
5 & 49 & 45 & 13 & 6 \\
6 & 10 & 48 & 118 & 7 \\
7 & 16 & 44 & 113 & 2 \\
8 & 13 & 61 & 2 & 1 \\
\hline
\end{tabular}



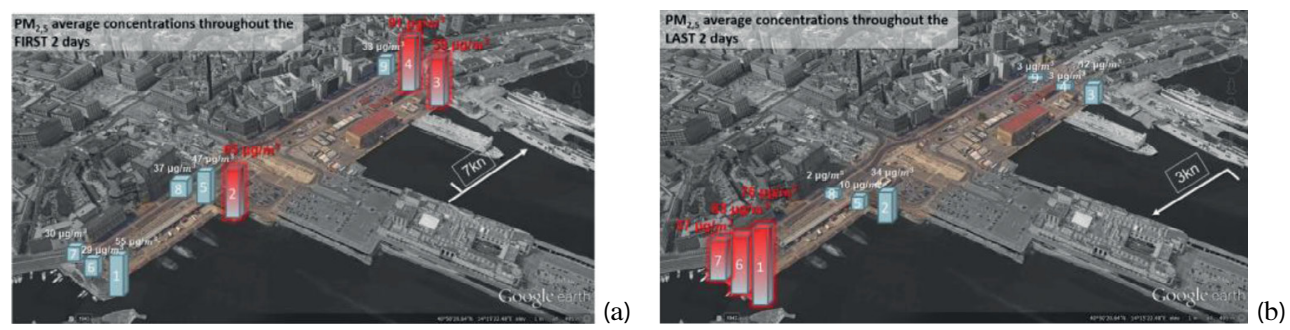

Figure 4: 3-D modelling of PM concentrations in first two days (a) and in second two days (b). The two cases are selected according to homogeneous weather stability conditions.

is located according to the position of each sampling point, is proportional to the recorded $\mathrm{PM}_{2.5}$ mean mass concentrations. The data are grouped in two figures (Figs. $4 \mathrm{a}$ and $4 \mathrm{~b}$ ), which are associated to two different homogeneous weather and atmospheric stability conditions.

\section{CONCLUSIONS}

Pollution monitoring in the urban environment is of paramount importance due to both the high number of exposed people and for finding adequate solutions towards a more sustainable lifestyle. This is particularly true in the case of areas where specific activities or intense emissions occur. In order to define the characteristics and the boundaries of the monitored area, a method for conducting a survey has been defined and tested. The chosen pollutant was $\mathrm{PM}_{2.5}$, due to its adverse impacts, as explained in the introduction. The case study for a brief test of such an approach was the Port of Naples, located within the city centre (S Italy).

The standard approach for defining the boundaries of a homogeneous area for $\mathrm{PM}_{2.5}$ with respect to specific activities emissions has been reviewed. Then, the method was tested in our case study. Our measurements, conducted using high-temporal and spatial resolution samplings, showed the effectiveness of such an approach, as a first step for planning a monitoring campaign. In fact, both the broad-scale limits of the area and the $\mathrm{PM}_{2.5}$ variability within the same area were identified. Vertical profiles, which have not been measured yet, would represent a further variable for defining a sub-grid for both the survey and the future monitoring. The use of innovative devices, having a higher spatial and temporal resolution with respect to standard reference instruments, has already proved to be effective means in supporting the survey. We are deepening the 3-D monitoring techniques as an approach to environmental diagnostics. Thus, this survey approach will be further implemented in the future.

A correct and adequate preliminary survey allows to better define the nature and characteristics of a monitoring network. This, in turn, supports a more effective process of identification and description of the measured sources. Furthermore, this is the first path towards the definition of adequate management options for minimizing the impacts of pollution in the urban environment.

\section{ACKNOWLEDGEMENT}

This work has been partially funded by Università degli Studi di Napoli Parthenope under 'Bando di sostegno alla ricerca individuale per il triennio 2015-2017'.

This work has been partially funded by Università degli Studi di Napoli Federico II under the STAR project SeaLEADS. 


\section{REFERENCES}

[1] Davis, D.L., Bell, M.L. \& Fletcher, T., A look back at the London Smog of 1952 and the half century since. Environmental Health Perspectives, 110(12), p. A734, 2002. DOI: 10.1289/ehp.110-a734

[2] Pope, C.A. \& Dockery, D.W., Health effects of fine particulate air pollution: Lines that connect. Journal of the Air and Waste Management Association, 56, pp. 709-742, 2006. DOI: 10.1080/10473289.2006.10464485

[3] Puustinen, A., Hämeri, K., Pekkanen, J., Kulmala, M., de Hartog, J., Meliefste, K., ten Brink, H., Kos, G., Katsouyanni, K., Karakatsani, A., Kotronarou, A., Kavouras, I., Meddings, C., Thomas, S., Harrison, R., Ayres, J.G., van der Zee, S. \& Hoek, G., Spatial variation of particle number and mass over four European cities. Atmospheric Environment, 41, pp. 6622-6636, 2007. DOI: 10.1016/j.atmosenv.2007.04.020

[4] Kawanaka, Y., Matsumoto, E., Sakamoto, K. \& Yun, S.J., Estimation of the contribution of ultrafine particles to lung deposition of particle-bound mutagens in the atmosphere. Science of the Total Environment, 409, pp. 1033-1038, 2011. DOI: 10.1016/j.scitotenv.2010.11.035

[5] Gualtieri, M., Ovrevik, J., Holme, J.A., Perrone, M.G., Bolzacchini, E., Schwarze, P.E. \& Camatini, M., Differences in cytotoxicity versus pro-inflammatory potency of different PM fractions in human epithelial lung cells. Toxicology In Vitro, 24, pp. 29-39, 2010. DOI: 10.1016/j.tiv.2009.09.013

[6] Schilirò, T., Alessandria, L., Degan, R., Traversi, D. \& Gilli, G., Chemical characterisation and cytotoxic effects in A549 cells of urban-air PM10 collected in Torino, Italy. Environmental Toxicology and Pharmacology, 29, pp. 150-157, 2010. DOI: 10.1016/j.etap.2009.12.005

[7] Bruggemann, E., Gerwig, H., Gnauk, T., Muller, K. \& Herrmann, H., Influence of seasons, air mass origin and day of the week on size-segregated chemical composition of aerosol particles at a kerbside. Atmospheric Environment, 43, pp. 2456-2463, 2009. DOI: $10.1016 /$ j.atmosenv.2009.01.054

[8] US Environmental Protection Agency (EPA), Air Quality Criteria for Particulate Matter, U.S. Environmental Protection Agency Office for Research and Development, EPA/600/ P-95/001aF, available at https://cfpub.epa.gov/ncea/risk/recordisplay.cfm?deid=2832 (accessed 19 December 2016).

[9] Billet, S., Abbas, I., Le Goff, J., Verdin, A., Andre, V., Lafargue, P.E., Hachimi, A., Cazier, F., Sichel, F., Shirali, P. \& Garcon, G., Genotoxic potential of polycyclic aromatic hydrocarbons-coated onto airborne particulate matter $(\operatorname{PM}(2.5))$ in human lung epithelial a549 cells. Cancer Letters, 270, pp. 144-155, 2008. DOI: 10.1016/j.canlet.2008.04.044

[10] Traversi, D., Degan, R., De Marco, R., Gilli, G., Pignata, C., Villani, S. \& Bono, R., Mutagenic properties of PM2.5 urban pollution in the Northern Italy: The nitrocompounds contribution. Environment International, 35, pp. 905-910, 2009. DOI: 10.1016/j. envint.2009.03.010

[11] Casazza, M., Maurino, V. \& Malandrino, M., Adult chronic exposure to neurotoxic metals associated with atmospheric aerosols: A case study in the urban area of Turin (NW Italy). Journal of Environmental Accounting and Management, 4(1), pp. 87-99, 2016. DOI: 10.5890/JEAM.2016.03.008

[12] Maher, B.A., Ahmed, I.A.M., Karloukovski, V., MacLaren, D.A., Foulds, P.G., Allsop, D., Mann, D.M.A., Torres-Jardón, R. \& Calderon-Garciduenas, L., Magnetite pollution nanoparticles in the human brain. PNAS, 113(39), pp. 10797-10801, 2016. DOI: 10.1073/ pnas. 1605941113 
[13] Montgomery, M.R., The urban transformation of the developing world. Science, 319, pp. 761-764, 2008. DOI: 10.1126/science. 1153012

[14] Zhang, D., Liu, J. \& Li, B., Tackling air pollution in China - What do we learn from the Great Smog of 1950s in London. Sustainability, 6, pp. 5322-5338, 2014. DOI: 10.3390/ su6085322

[15] Wallace, J., Corr, D. \& Kanaroglou, P., Topographic and spatial impacts of temperature inversions on air quality using mobile air pollution surveys. Science of the Total Environment, 408, pp. 5086-5096, 2010. DOI: 10.1016/j.scitotenv.2010.06.020

[16] Kelly, K.E., Jaramillo, I.C., Quintero-Nunez, M., Wagner, D.A., Collins, K., Meuzelaar, H.L. \& Lighty, J.S., Low-wind/high particulate matter episodes in the Calexico/Mexicali region. Journal of the Air and Waste Management Association, 60, pp. 1476-1486, 2010. DOI: $10.3155 / 1047-3289.60 .12 .1476$

[17] Casazza, M., Gilli, G., Piano, A. \& Alessio, S., Thirty-years assessment of size-Fractionated particle mass concentrations in a polluted urban area and its implications for the regulatory framework. Journal of Environmental Accounting and Management, 1(3), pp. 48-57, 2013. DOI: 10.5890/JEAM.2013.08.004

[18] Casazza, M., Possibility of secondary sub-micron aerosol mass concentrations forecasting: A case study toward the possibility of a future nowcasting approach. Journal of Environmental Accounting and Management, 3(1), pp. 59-67, 2015. DOI: 10.5890/ JEAM.2015.03.005

[19] Behera, S.M. \& Sharma, M., Degradation of SO2, NO2 and NH3 leading to formation of secondary inorganic aerosols: an environmental chamber study. Atmospheric Environment, 45, pp. 4015-4024, 2011. DOI: 10.1016/j.atmosenv.2011.04.056

[20] Ledoux, F., Courcot, L., Courcot, D., Aboukaïs, A. \& Puskaric, E., A summer and winter apportionment of particulate matter at urban and rural areas in northern France. Atmospheric Research, 82, pp. 633-642, 2006. DOI: 10.1016/j.atmosres.2006.02.019

[21] Croft, B., Lohmann, U., Martin, R.V., Stier, P., Wurzler, S., Feichter, J., Hoose, C., Heikkil, U., van Donkelaar, A. \& Ferrachat, S., Influences of in-cloud aerosol scavenging parameterizations on aerosol concentrations and wet deposition in ECHAM5HAM. Atmospheric Chemistry and Physics, 10, pp. 1511-1543, 2010. DOI: 10.5194/ acp-10-1511-2010

[22] Mircea, M., Stefan, S. \& Fuzzi, S., Precipitation scavenging coefficient: Influence of measured aerosol and raindrop size distributions. Atmospheric Environment, 34, pp. 5169-5174, 2000. DOI: 10.1016/S1352-2310(00)00199-0

[23] Chaubey, J.P., Moorthy, K.K., Babu, S.S., Nair, V.S. \& Tiwari, A., Black carbon aerosols over coastal Antarctica and its scavenging by snow during the Southern Hemispheric summer. Journal of Geophysical Research, 115(D10), pp. 2156-2202, 2010. DOI: 10.1029/2009JD013381

[24] Lu, C., Niu, S., Tang, L., Lv, J., Zhao, L. \& Zhu, B., Chemical composition of fog water in Nanjing area of China and its related fog microphysics. Atmospheric Research, 97, pp. 47-69, 2010. DOI: 10.1016/j.atmosres.2010.03.007

[25] Agrawal, H., Welch, W.A., Miller, J.W. \& Cocker, D.R., Emission measurements from a crude oil tanker at Sea. Environmental Science \& Technology, 42, pp. 7098-7103, 2008. DOI: 10.1021/es703102y

[26] Eyring, V., Isaksen, I.S.A., Berntsen, T., Collins WJ, Corbett JJ, Endresen O, Oyvind Endresen, O., Grainger, R.G., Moldanova, J., Schlager, H. \& Stevenson, D.S., Transport impacts on atmosphere and climate: shipping. Atmospheric Environment, 44, pp. 4735-4771, 2010. DOI: $10.1016 /$ j.atmosenv.2009.04.059 
[27] Healy, R.M., O’Connor, I.P., Hellebust, S., Allanic, A., Sodeau, J.R. \& Wenger, J.C., Characterisation of single particles from in-port ship emissions. Atmospheric Environment, 43, pp. 6408-6414, 2009. DOI: 10.1016/j.atmosenv.2009.07.039

[28] Eyring, V., Köhler, H.W., van Aardenne, J. \& Lauer, A., Emissions from international shipping: 1. The last 50 years. Journal of Geophysical Research, 110(D17), pp. 2156-2202, 2005. DOI: 10.1029/2004JD005619

[29] Saxe, H. \& Larsen, T., Air pollution from ships in three Danish ports. Atmospheric Environment, 38, pp. 4057-4067, 2004. DOI: 10.1016/j.atmosenv.2004.03.055

[30] Dalsøren, S.B., Eide, M.S., Endresen, Ø., Mjelde, A., Gravir, G. \& Isaksen, I.S.A., Update on emissions and environmental impacts from the international fleet of ships: the contribution from major ship types and ports. Atmospheric Chemistry \& Physics, $\mathbf{9}$, pp. 2171-2194, 2009. DOI: 10.5194/acp-9-2171-2009

[31] Dore, A.J., Vieno, M., Tang, Y.S., Dragosits, U., Dosio, A., Weston, K.J. \& Sutton, M.A., Modelling the atmospheric transport and deposition of sulphur and nitrogen over the United Kingdom and assessment of the influence of SO2 emissions from international shipping. Atmospheric Environment, 41, pp. 2355-2367, 2007. DOI: 10.1016/j. atmosenv.2006.11.013

[32] Viana, M., Hammingh, P., Colette, A., Querol, X., Degraeuwe; B., de Vlieger, I. \& van Aardenne, J., Impact of maritime transport emissions on coastal air quality in Europe. Atmospheric Environment, 90, pp. 96-105, 2014. DOI: 10.1016/j.atmosenv.2014.03.046

[33] Berechman, J. \& Tseng, P.-H., Estimating the environmental costs of port related emissions: The case of Kaohsiung. Transportation Research Part D, 17, pp. 35-38, 2012. DOI: $10.1016 /$ j.trd.2011.09.009

[34] Zhao, M., Yan Zhang, Y., Ma, W., Fu, Q., Yang, X., Li, C., Zhou, B., Yua, Q. \& Chen, L., Characteristics and ship traffic source identification of air pollutants in China's largest port. Atmospheric Environment, 64, pp. 277-286, 2013. DOI: 10.1016/j.atmosenv.2012.10.007

[35] Cesari, D., Genga, A., Ielpo, P., Siciliano, M., Mascolo, G., Grasso, F.M. \& Contini, D., Source apportionment of PM2.5 in the harbour-industrial area of Brindisi (Italy): Identification and estimation of the contribution of in-port ship emissions. Science of the Total Environment, 497-498, pp. 392-400, 2014. DOI: 10.1016/j. scitotenv.2014.08.007

[36] Sofowote, U.M., Rastogi, A.K., Debosz, J. \& Hopke, P.K., Advanced receptor modeling of near-real-time, ambient PM2.5 and its associated components collected at an urbanindustrial site in Toronto, Ontario. Atmospheric Pollution Research, 5, pp. 13-23, 2014. DOI: 10.5094/APR.2014.003

[37] Marenco, L. \& Cantillo, V., A framework to evaluate particulate matter emissions in bulk material ports: Case study of Colombian coal terminals. Maritime Policy \& Management, 42(4), pp. 335-361, 2015. DOI: 10.1080/03088839.2013.877171

[38] Prati, M.V., Costagliola, M.A., Quaranta, F. \& Murena, F., Assessment of ambient air quality in the port of Naples. Journal of the Air \& Waste Management Association, 65(8), pp. 970-979, 2015. DOI: 10.1016/j.atmosenv.2012.10.007

[39] US Environmental Protection Agency (EPA), Guidance for Network Design and Optimum Site Exposure for PM2.5 and PM10, U.S. Environmental Protection Agency, Office of Air Quality and Standars, EPA-454/R-99-022, available at www3.epa.gov/ttnamti1/ files/ambient/pm25/network/r-99-022.pdf (accessed 19 December 2016).

[40] Pinto, J.P., Lefohn, A.S., \& Shadwick, D.S., Spatial variability of PM2.5 in urban areas in the United States. Journal of the Air and Waste Management Association, 54(4), pp. 440-449, 2004. DOI: 10.1080/10473289.2004.10470919 
[41] Muller, C.L., Chapman, L., Grimmond, C.S.B., Young, D.T. \& Cai, X., Sensors and the city: A review of urban meteorological networks. International Journal of Climatology, 33, pp. 1585-1600, 2013. DOI: 10.1002/joc.3678

[42] Chiri, G.M. \& Giovagnorio, I., The role of the city's shape in urban sustainability. International Transaction Journal of Engineering, Management, \& Applied Sciences \& Technologies, 3(3), pp. 245-258, 2012.

[43] Schweizer, C., Edwards, R.D., Bayer-Oglesby, L., Gauderman, W.J., Ilacqua, V., Jantunen, M.J., Lai, H.K., Nieuwenhuijsen, M. \& Künzli, N., Indoor time-microenvironment-activity patterns in seven regions of Europe. Journal of Exposure Science and Environmental Epidemiology, 17, pp. 170-181, 2007. DOI: 10.1038/sj.jes.7500490

[44] Mohammed, M.O.A., Song, W.-W., Ma, W.-L., Li, W.-L., Ambuchi, J.J., Thabit, M. \& Li, Y.-F., Trends in indoor-outdoor PM2.5 research: A systematic review of studies conducted during the last decade (2003-2013). Atmospheric Pollution Research, 6(5), pp. 893-903, 2015. DOI: 10.5094/APR.2015.099

[45] Erisman, J.W., Weijers, E., Khlystov, A. \& Kos, G., Variability of particulate matter concentrations along roads and motorways determined by a moving measurement unit. Atmospheric Environment, 38, pp. 2993-3002, 2004.DOI: 10.1016/j.atmosenv.2004.02.045

[46] Sauerbrey, G., Verwendung von Schwingquarzen zur Wägung dünner Schichten und zur Mikrowägung. Zeitschrift für Physik, 155(2), pp. 206-222, 1959. DOI: 10.1007/ BF01337937

[47] Errico, A., Angelino, C.V., Cicala, L., Persechino, G., Ferrara, C., Lega, M., Vallario, A., Parente, C., Masi, G., Gaetano, R., Scarpa, G., Amitrano, D., Ruello, G., Verdoliva, L. \& Poggi, G., Detection of environmental hazards through the feature-based fusion of optical and SAR data: A case study in southern Italy. International Journal of Remote Sensing, 36(13), pp. 3345-3367, 2015 DOI: 10.1016/S0262-8856(03)00137-9

[48] Lega, M. \& Persechino, G., GIS and infrared aerial view: Advanced tools for the early detection of environmental violations. WIT Transactions on Ecology and the Environment, 180, pp. 225-235, 2014. DOI: 10.2495/WM140191

[49] Lega, M., Ferrara, C., Persechino, G. \& Bishop, P., Remote sensing in environmental police investigations: Aerial platforms and an innovative application of thermography to detect several illegal activities. Environmental Monitoring and Assessment, 186(12), pp. 8291-8830, 2014. DOI: 10.1007/s10661-014-4003-3

[50] Persechino, G., Lega, M., Romano, G., Gargiulo, F. \& Cicala, L., IDES project: An advanced tool to investigate illegal dumping. WIT Transactions on Ecology and the Environment, 173, 603-614, 2013. DOI: 10.2495/SDP130501

[51] Lega, M., D’Antonio, L. \& Napoli, R.M.A., Cultural heritage and waste heritage: Advanced techniques to preserve cultural heritage, exploring just in time the ruins produced by disasters and natural calamities. WIT Transactions on Ecology and the Environment, 140, 123-134, 2010. DOI: 10.2495/WM100121

[52] Persechino, G., Schiano, P., Lega, M., Napoli, R.M.A., Ferrara, C. \& Kosmatka, J., Aerospace-based support systems and interoperability: The solution to fight illegal dumping. WIT Transactions on Ecology and the Environment, 140, pp. 203-214, 2010. DOI: 10.2495/WM100191

[53] Lega, M. \& Napoli, R.M.A., A new approach to solid waste landfill aerial monitoring. WIT Transactions on Ecology and the Environment, 109, pp. 193-199, 2008. DOI: 10.2495/WM080211 
[54] Teta, R., Della Sala, G., Glukhov, E., Gerwick, L., Gerwick, W.H., Mangoni, A. \& Costantino, V., Combined LC-MS/MS and molecular networking approach reveals new cyanotoxins from the 2014 cyanobacterial bloom in Green Lake, Seattle. Environmental Science and Technology, 49(24), pp. 14301-14310,2015. DOI: 10.1021/acs.est.5b04415

[55] Costantino, V., Fattorusso, E., Imperatore, C., Mangoni, A. \& Teta, R., Amphiceramide $\mathrm{A}$ and $\mathrm{B}$, novel glycosphingolipids from the marine sponge Amphimedon compressa. European Journal of Organic Chemistry, 13, pp. 2112-2119, 2009. DOI: 10.1002/ ejoc. 200801230

[56] Teta, R., Della Sala, G., Mangoni, A., Lega, M. \& Costantino, V., Tracing cyanobacterial blooms to assess the impact of wastewaters discharges on coastal areas and lakes. International Journal of Sustainable Development and Planning, 11(5), pp. 804-811, 2016. DOI: 10.2495/SDP-V11-N5-804-811

[57] Pasquill, F., Atmospheric Diffusion. Ellis Horwood Limited: Chichester, 1974. 